\title{
Maternal Hypothyroidism and Sensorineural Disability
}

\author{
Ahmed RG* \\ Zoology Department, Beni-Suef University, Egypt \\ Submission: March 03, 2018; Published: April 27, 2018 \\ *Corresponding author: Ahmed RG, Division of Anatomy and Embryology, Zoology Department, Faculty of Science, Beni-Suef University, Egypt, \\ Tel: 002-010-91471828; Email: ahmedragab08@gmail.com
}

\section{Commentary}

Maternal thyroid hormones (THs; 3,5,3'-triiodothyronine (T3) and thyroxin (T4)) exert vital roles throughout the development and show a permissive role in the neurological functions, in particular the sensorineural actions. The actions of THs can be mediated through the genomic and non-genomic pathways. On the other hand, there are associations between the maternal hypothyroidism and neonatal sensorineural deficits. A gestational hypothyroidism displays sensory and motor deficits, grave cognitive, permanent long-lasting variations in child brain structure, and neurodevelopmental disorders. During prenatal and early postnatal periods, any disruption in the levels of T4 or T3 can lead to irreversible disorders in sensorimotor and intelligence function, psychotic behavior, mental retardation, depression, coma and several morphological variations in the brain.

These disorders can increase the risk of memory and learning impairment and dementia. In human, Magri et al. [1] reported that hypothyroidism can cause asymptomatic smallfiber sensory neuropathy. In fact, it has been proposed that congenital hypothyroidism increases the rate of sensorineural hearing loss and motor disability in childhood and adulthood. More interestingly, several authors reported that hypothyroidism can cause a demyelination in the peripheral nerve, sensorimotor neuropathy or polyneuropathy, and fibrillation, diminish the nerve conduction velocity, and delay the relaxation phase of deep tendon reflexes. On the other hand, adult-onset hypothyroidism in humans can cause deafness and multiple defects in taste and smell. Alternatively, adult-onset hypothyroidism in mice can cause several defects in odor discrimination, and decrease the hearing capabilities at adulthood. Thus, it is also worth noticing that normal sensorineural development in early life is favorably dependent on the levels of maternal THs. As well, maternal hypothyroidism may be associated with multiple sensorineural defects and brain disorders. Therefore, the ideal regulation of gestational thyroid function is significant not only for her own health but probably also for the long-term health of her child.
Also, motor proficiency ought to be achieved in preschool age children to distinguish the sensorineural deficits early. Further studies are required to describe the mechanisms of maternal thyroid-associated sensorineural disease [2-113].

\section{References}

1. Magri F, Buonocore M, Oliviero A (2010) Intraepidermal nerve fiber density reduction as a marker of preclinical asymptomatic small-fiber sensory neuropathy in hypothyroid patients. Eur J Endocrinol 163: 279-284.

2. Ahmed OM, Abd El-Tawab SM, Ahmed RG (2010) Effects of experimentally induced maternal hypothyroidism and hyperthyroidism on the development of rat offspring: I- The development of the thyroid hormones-neurotransmitters and adenosinergic system interactions. Int J Dev Neurosci 28: 437-454.

3. Ahmed OM, Ahmed RG (2012) Hypothyroidism. In: D. Springer (Ed.), A New Look At Hypothyroidism. In Tech Open Access Publisher, London, UK, pp. 1-20.

4. Ahmed OM, Ahmed RG, El-Gareib AW, El-Bakry AM, Abd El-Tawab SM (2012) Effects of experimentally induced maternal hypothyroidism and hyperthyroidism on the development of rat offspring: II-The developmental pattern of neurons in relation to oxidative stress and antioxidant defense system. Int J Dev Neurosci 30(6): 517-537.

5. Ahmed OM, El-Gareib AW, El-bakry AM, Abd El-Tawab SM, Ahmed RG (2008) Thyroid hormones states and brain development interactions. Int J Dev Neurosci 26(2): 147-209.

6. Ahmed RG (2011) Perinatal 2,3,7,8-tetrachlorodibenzo-p-dioxin exposure alters developmental neuroendocrine system. Food Chem Toxicology 49: 1276-1284.

7. Ahmed RG (2012) Maternal-newborn thyroid dysfunction. In: Ahmed RG (Ed.), the Developmental Neuroendocrinology, Germany: LAP LAMBERT Academic Publishing GmbH \& Co KG, Germany, pp. 1-369.

8. Ahmed RG (2012) Maternal-fetal thyroid interactions, Thyroid Hormone. In: Agrawal NK (Ed.), In Tech Open Access Publisher, London, UK, pp. 125-156.

9. Ahmed RG (2013) Early weaning PCB 95 exposure alters the neonatal endocrine system: thyroid adipokine dysfunction. J Endocrinol 219 (3): 205-215.

10. Ahmed RG (2014) Editorial: Do PCBs modify the thyroid-adipokine axis during development? Annals Thyroid Res 1(1): 11-12. 


\section{Global Journal of Pharmacy \& Pharmaceutical Sciences}

11. Ahmed RG (2015) Advances in hypothyroidism treatment. Avid Science Publications level 6, Hyderabad, Telangana, India, pp. 1-40.

12. Ahmed RG (2015) Hypothyroidism and brain developmental players. Thyroid Research J 8(2): 1-12.

13. Ahmed RG (2015) Editorials and Commentary: Maternofetal thyroid action and brain development. J of Advances in Biology 7(1): 12071213.

14. Ahmed RG (2016) Gestational dexamethasone alters fetal neuroendocrine axis. Toxicology Letters 258: 46-54.

15. Ahmed RG (2016) Neonatal polychlorinated biphenyls-induced endocrine dysfunction. Ann. Thyroid Res 2 (1): 34-35.

16. Ahmed RG (2016) Maternal iodine deficiency and brain disorders. Endocrinol Metab Syndr 5: 223.

17. Ahmed RG (2016d) Maternal bisphenol A alters fetal endocrine system Thyroid adipokine dysfunction. Food Chem Toxicology 95: 168-174.

18. Ahmed RG (2017) Developmental thyroid diseases and GABAergic dysfunction. EC Neurology 8(1): 02-04.

19. Ahmed RG (2017) Hyperthyroidism and developmental dysfunction. Arch Med 9 4: 6.

20. Ahmed RG (2017) Anti-thyroid drugs may be at higher risk for perinatal thyroid disease. EC Pharmacology and Toxicology 4(4): 140-142.

21. Ahmed RG (2017) Perinatal hypothyroidism and cytoskeleton dysfunction. Endocrinol Metab Syndr 6: 271.

22. Ahmed RG (2017) Developmental thyroid diseases and monoaminergic dysfunction. Advances in Applied Science Research 8(3): 01-10.

23. Ahmed RG (2017) Hypothyroidism and brain development. J Anim Res Nutr 2(2): 13

24. Ahmed RG (2017) Antiepileptic drugs and developmenta neuroendocrine dysfunction: Every why has A Wherefore. Arch Med 9(6): 2 .

25. Ahmed RG (2017) Gestational prooxidant-antioxidant imbalance may be at higher risk for postpartum thyroid disease. Endocrinol Metab Syndr 6: 279.

26. Ahmed RG (2017) Synergistic actions of thyroid-adipokines axis during development. Endocrinol Metab Syndr 6: 280.

27. Ahmed RG (2017) Thyroid-insulin dysfunction during development International Journal of Research Studies in Zoology 3(4): 73-75.

28. Ahmed RG (2017) Developmental thyroid diseases and cholinergic imbalance. International Journal of Research Studies in Zoology 3(4) 70-72.

29. Ahmed RG (2017) Thyroid diseases and developmental adenosinergic imbalance. Int J Clin Endocrinol 1(2): 053-055.

30. Ahmed RG (2017) Maternal anticancer drugs and fetal neuroendocrine dysfunction in experimental animals. Endocrinol Metab Syndr 6: 281.

31. Ahmed RG (2017) Letter: Gestational dexamethasone may be at higher risk for thyroid disease developing peripartum. Open Journal Of Biomedical \& Life Sciences Ojbili 3(2): 01-06.

32. Ahmed RG (2017) Deiodinases and developmental hypothyroidism. EC Nutrition 11(5): 183-185

33. Ahmed RG (2017) Maternofetal thyroid hormones and risk of diabetes. Int J of Res Studies in Medical and Health Sciences 2(10): 18-21.

34. Ahmed RG (2017) Association between hypothyroidism and renal dysfunctions. International Journal of Research Studies in Medical and Health Sciences 2(11): 1-4.
35. Ahmed RG (2017) Maternal hypothyroidism and lung dysfunction International Journal of Research Studies in Medical and Health Sciences 2(11): 8-11.

36. Ahmed RG (2017) Endocrine disruptors; possible mechanisms for inducing developmental disorders. International journal of basic science in medicine IJBSM 2(4): 157-160.

37. Ahmed RG (2017) Maternal thyroid hormones trajectories and neonatal behavioral disorders. ARC Journal of Diabetes and Endocrinology 3(2): $18-21$

38. Ahmed RG (2017) Maternal thyroid dysfunction and neonatal cardiac disorders. Insights Biol Med 1: 092-096.

39. Ahmed RG (2018) Maternal hypothyroidism and neonatal testicular dysfunction. International Journal of Research Studies in Medical and Health Sciences 3(1): 8-12.

40. Ahmed RG (2018) Maternal hypothyroidism and neonatal depression: Current perspective. International Journal of Research Studies in Zoology 4(1): 6-10.

41. Ahmed RG (2018) Non-genomic actions of thyroid hormones during development. App Clin Pharmacol Toxicol: ACPT-108.

42. Ahmed RG (2018) Maternal thyroid function and placental hemodynamics. ARC Journal of Animal and Veterinary Sciences 4(1): 9-13.

43. Ahmed RG (2018) Interactions between thyroid and growth factors during development. ARC Journal of Diabetes and Endocrinology 4(1): $1-4$.

44. Ahmed RG (2018) Maternal thyroid hormones and neonatal appetite ARC Journal of Nutrition and Growth 4(1): 18-22.

45. Ahmed RG (2018) Genomic actions of thyroid hormones during development. ARC Journal of Diabetes and Endocrinology 4(1): 5-8.

46. Ahmed RG (2018) Dysfunction of maternal thyroid hormones and psychiatric symptoms. American Research Journal of Endocrinology 2(1): 1-6.

47. Ahmed RG (2018) Is there a connection between maternal hypothyroidism and developing autism spectrum disorders? ARC Journal of Neuroscience 3(1): 5-8.

48. Ahmed RG (2018) Maternal thyroid dysfunctions and neonatal bone maldevelopment. American Research Journal of Endocrinology 28(5): 371-389.

49. Ahmed RG (2018) Maternal thyroid disorders and risk of neonatal seizure: Current perspective. ARC Journal of Neuroscience 3(1): 21-25.

50.Ahmed RG (2018) Gestational dioxin acts as developing neuroendocrine-disruptor. EC Pharmacology and Toxicology 6(3): 96100.

51. Ahmed RG (2018) Maternal thyroid dysfunction and risk of neonatal stroke. ARC Journal of Animal and Veterinary Sciences 4(1): 22-26.

52. Ahmed RG (2018) Maternal thyroid disorders and developing skin dysfunctions. ARC Journal of Dermatology 3(1): 13-17.

53. Ahmed RG (2018) Maternal hypothyroidism-milk ejections: What is the link? ARC Journal of Nutrition and Growth 4(1): 29-33.

54. Ahmed RG (2018) Does maternal antepartum hypothyroidism cause fetal and neonatal hyponatremia? ARC Journal of Diabetes and Endocrinology 4(1): 2018.

55. Ahmed RG (2018) Maternal hypothyroidism and rheumatoid arthritis International Journal of Research Studies in Medical and Health Sciences Volume 3(2): 1-5. 


\section{Global Journal of Pharmacy \& Pharmaceutical Sciences}

56. Ahmed RG (2018) Developmental thyroid and skeletal muscle dysfunction. ARC Journal of Diabetes and Endocrinology 4(1): 2018.

57. Ahmed RG (2018) Hyperthyroidism and renal disorders. ARC Journal of Animal and Veterinary Sciences 4(2): 10.20431/2455-2518.0402001

58. Ahmed RG, Abdel-Latif M, Ahmed F (2015) Protective effects of GM-CSF in experimental neonatal hypothyroidism. International Immunopharmacology 29(2): 538-543.

59. Ahmed RG, Abdel-Latif M, Mahdi E, El-Nesr K (2015) Immune stimulation improves endocrine and neural fetal outcomes in a model of maternofetal thyrotoxicosis. Int Immunopharmacol 29(2): 714-721.

60. Ahmed RG, Davis PJ, Davis FB, De Vito P, Farias RN, et al. (2013) Nongenomic actions of thyroid hormones: from basic research to clinical applications. An update. Immunology Endocrine \& Metabolic Agents in Medicinal Chemistry 13(1): 46-59.

61. Ahmed RG, El-Gareib AW (2014) Lactating PTU exposure: I- Alters thyroid-neural axis in neonatal cerebellum. Eur J of Biol and Medical Sci Res 2(1): 1-16.

62. Ahmed RG, El-Gareib AW (2017) Maternal carbamazepine alters fetal neuroendocrine-cytokines axis. Toxicology 382: 59-66.

63. Ahmed RG, El-Gareib AW, Incerpi S (2014) Lactating PTU exposure: II- Alters thyroid-axis and prooxidant-antioxidant balance in neonatal cerebellum. Int Res J of Natural Sciences 2(1): 1-20.

64. Ahmed RG, El-Gareib AW, Shaker HM (2018) Gestational 3,3',4,4',5-pentachlorobiphenyl (PCB 126) exposure disrupts fetoplacental unit: Fetal thyroid-cytokines dysfunction. Life Sciences 192: 213-220.

65. Ahmed RG, Incerpi S (2013) Gestational doxorubicin alters fetal thyroid-brain axis. Int J Devl Neuroscience 31: 96-104.

66. Ahmed RG, Incerpi S, Ahmed F, Gaber A (2013) The developmental and physiological interactions between free radicals and antioxidant: Effect of environmental pollutants. J of Natural Sci Res 3(13): 74-110.

67. Ahmed RG, Walaa GH, Asmaa FS (2018) Suppressive effects of neonatal bisphenol A on the neuroendocrine system. Toxicology and Industrial Health Journal 1: 748233718757082.

68. Anderson GW, Mariashm CN (2002) Molecular Aspects of Thyroid Hormone-Regulated Behavior. Hormones Brain and Behavior 31(2): 539-566.

69. Axelstad M, Hansen PR, Boberg J, Bonnichsen M, Nellemann C, et al (2008) Developmental neurotoxicity of propylthiouracil (PTU) in rats: relationship between transient hypothyroxinemia during development and long-lasting behavioural and functional changes. Toxicol Appl Pharmacol 232(1): 1-13.

70. Bargagna S, Canepa G, Costagli C (2000) Neuropsychological followup in early-treated congenital hypothyroidism: A problemoriented approach. Thyroid 10(3) 243-249.

71. Baskoy K, Ay SA, Altundag A, Kurt O, Salihoglu M, et al. (2016) Is there any effect on smell and taste functions with levothyroxine treatment in subclinical hypothyroidism? PLoS One 11: e0149979.

72. Bellman SC, Davies A, Fuggle PW, Grant DB, Smith I (1996) Mild impairment of neuro-otological function in early treated congenital hypothyroidism. Arch Dis Child 74(3): 215-218.

73. Calloni GW, Penno CA, Cordova FM (2005) Congenital hypothyroidism alters the phosphorylation of ERK1/2 and p38MAPK in the hippocampus of neonatal rats. Developmental Brain Research 154(1): 141-145.

74. Candelotti E, De Vito P, Ahmed RG, Luly P, Davis PJ, et al. (2015) Thyroid hormones crosstalk with growth factors: Old facts and new hypotheses. Immun Endo \& Metab Agents in Med Chem 15: 71-85.
75. Darras VM, Van Herck SL, Heijlen M, De Groef B (2011) Thyroid hormone receptors in two model species for vertebrate embryonic development: chicken and zebrafish. J Thyroid Res 2: 402320.

76. de Escobar GM, Obregon MJ, del Rey FE (2004) Maternal thyroid hormones early in pregnancy and fetal brain development. Best Pract Res Clin Endocrinol Metab 18(2): 225-248.

77. De Vito P, Candelotti E, Ahmed RG, Luly P, Davis PJ, et al. (2015) Role of thyroid hormones in insulin resistance and diabetes. Immun Endoc \& Metab Agents in Med Chem 15: 86-93.

78. Dennis MS (2005) Non-Alzheimer Dementias.

79. Desouzo LA, Ladiwala U, Daniel SM (2005) Thyroid hormone regulates hippocampal neurogenesis in the adult rat brain. Mol Cell Neurosci 29(3): 414-426.

80. Dong H, Wade M, Williams A (2005) Molecular insight into the effects of hypothyroidism on the developing cerebellum. Biochemical and Biophysical Research Communications 30(4): 1182-1193.

81. Duyff RF, Van den Bosch J, Laman DM, van Loon BJ, Linssen WH (2000) Neuromuscular findings in thyroid dysfunction: A prospective clinical and electrodiagnostic study. J Neurol Neurosurg Psychiatry 68(6): 750755 .

82. Dyck PJ, Lambert EH (1970) Polyneuropathy associated with hypothyroidism. J Neuropathol Exp Neurol 29(4): 631-658.

83. El-bakry AM, El-Ghareeb AW, Ahmed RG (2010) Comparative study of the effects of experimentally-induced hypothyroidism and hyperthyroidism in some brain regions in albino rats. Int J Dev Neurosci 28(5): 371-389.

84. El-Ghareeb AA, El-Bakry AM, Ahmed RG, Gaber A (2016) Effects of zinc supplementation in neonatal hypothyroidism and cerebellar distortion induced by maternal carbimazole. Asian Journal of Applied Sciences 4(04): 1030-1040.

85. Frezzato RC, Santos DC, Goto MM, Ouro MP, Santos CT, et al. (2017) Fine motor skills and expressive language: a study with children with congenital hypotyreoidism. CoDAS 29(1): e20160064.

86. Ghassabian A, Bongers-Schokking JJ, Henrichs J, Jaddoe VWV, Visser TJ, et al. (2011) Maternal thyroid function during pregnancy and behavioral problems in the offspring: the generation R study. Pediatr Res 69(5): 454-459.

87. Gilbert ME, Rovet J, Chen Z, Koibuchi N (2012) Developmental thyroid hormone disruption: prevalence, environmental contaminants and neurodevelopmental consequences. Neurotoxicology 33(4): 842-852.

88. Guadaño-Ferraz A, Escamez MJ, Raussell E, Bernal J (1999) Expression of type 2 iodothyronine deiodinase in hypothyroid rat brain indicates an important role of thyroid hormone in the development of specific primary sensory systems. J Neurosci 19(9): 3430-3439.

89. Incerpi S, Hsieh MT, Lin HY, Cheng GY, De Vito P, et al. (2014) Thyroid hormone inhibition in L6 myoblasts of IGF-I-mediated glucose uptake and proliferation: new roles for integrin $\alpha v \beta 3$. Am J Physiol Cell Physiol 307(4): C150-C161.

90. Johnson KM, Lema SC (2011) Tissue-specific thyroid hormone regulation of gene transcripts encoding iodothyronine deiodinases and thyroid hormone receptors in striped parrotfish (Scarus iseri). Gen Comp Endocrinol 172(3): 505-517.

91. Kececi H, Degirmenci Y (2006) Hormone replacement therapy in hypothyroidism and nerve conduction study. Neurophysiol Clin 36(2): 79-83.

92. Knipper M, Zinn C, Maier H, Praetorius M, Rohbock KK, et al. (2000) Thyroid hormone deficiency before the onset of hearing causes irreversible damage to peripheral and central auditory systems. J Neurophysiol 83(5): 3101-3112. 
93. Leonard JL (2008) Non-genomic actions of thyroid hormone in brain development. Steroids 73(9): 1008-1012.

94. Lichtenberger-Geslin L, Dos Santos S, Hassani Y, Ecosse E, Van Den Abbeele T, et al. (2013) Factors associated with hearing impairment in patients with congenital hypothyroidism treated since the neonatal period: A national population-based study. J Clin Endocrinol Metab 98(9): 3644-3652.

95. Moog NK, Heima CM, Entringer S, Kathmann N, Wadhw PD, et al. (2017) Childhood maltreatment is associated with increased risk of subclinical hypothyroidism in pregnancy. Psychoneuroendocrinology 84: 190-196.

96. Nandi-Munshi D, Taplin CE (2015) Thyroid-related neurological disorders and complications in children. Pediatric Neurology 52(2015): 373-382.

97. Nemni R, Bottacchi E, Fazio R (1987) Polyneuropathy in hypothyroidism: Clinical, electrophysiological and morphological findings in four cases. J Neurol Neurosurg Psychiatry 50(11): 14541460.

98. Ng L, Hernandez A, He W, Ren T, Srinivas M, et al. (2009) A protective role for type 3 deiodinase, a thyroid hormoneinactivating enzyme, in cochlear development and auditory function. Endocrinology 150(4): 1952-1960.

99. Nunez C, Celi F, Ng L (2008) Multigenic control of thyroid hormone functions in the nervous system. Molecular and Cellular Endocrinology 287(1): 1-12.

100. Oerbeck B, Sundet K, Kase BF, Heyerdahl S (2003) Congenital hypothyroidism: influence of disease severity and L-thyroxine treatment on intellectual, motor, and school-associated outcomes in young adults. Pediatrics 112(4): 923-930.

101. Osterweil D, Syndulko K, Cohen SN (1992) Cognitive function in nondemented older adults with hypothyroidism. J Am Geriatr Soc 40(4): 325-335.

102. Pakkila F, Mannisto T, Pouta A, Hartikainen AL, Ruokonen A, et al (2014) The impact of gestational thyroid hormone concentrations on ADHD symptoms of the child. J Clin Endocrinol Metab 99(1): E 1-8.

103. Pollard JD, McLeod JG, Honnibal TG, Verheijden MA (1982) Hypothyroid polyneuropathy. clinical, electrophysiological and nerve biopsy findings in two cases. J Neurol Sci 53(3): 461-471.
104. Raymaekers SR, Darras VM (2017) Thyroid hormones and learningassociated neuroplasticity. General and Comparative Endocrinology 247: 26-33.

105. Roberts CG, Ladenson PW (2004) Hypothyroidism. Lancet 363(9411): 793-803.

106. Shimokawa N, Yousefi B, Morioka S, Yamaguchi S, Ohsawa A (2014) Altered cerebellum development and dopamine distribution in a rat genetic model with congenital hypothyroidism. J Neuroendocrinol 26(3): 164-175.

107. Smith JW, Evans AT, Costal B, Smythe JW (2002) Thyroid hormones, brain function and cognition: a brief review. Neuroscience and Biobehavioral Reviews 26(1): 45-60.

108. Sulkowski ZL, Chen T, Midha S, Zavacki AM, Sajdel-Sulkowska EM (2012) Maternal thimerosal exposure results in aberrant cerebellar oxidative stress, thyroid hormone metabolism, and motor behavior in rat pups; sex- and straindependent effects. Cerebellum 11(2): 575586.

109. Tong H, Chen GH, Liu RY, Zhou JN (2007) Age-related learning and memory impairments in adult-onset hypothyroidism in Kunming mice. Physiol. Behav 91(2): 290-298.

110. Van Herck SLJ, Geysens S, Bald E, Chwatko G, Delezie E, et al. (2013) Maternal transfer of methimazole and effects on thyroid hormone availability in embryonic tissues. Endocrinol 218(1): 105-115.

111. Williams F, Watson J, Ogston S, Hume R, Willatts P, et al (2012) Mild maternal thyroid dysfunction at delivery of infants born $\leq 34$ weeks and neurodevelopmental outcome at 5.5 years. J Clin Endocrinol Metab 97: 1977-1985.

112. Willoughby KA, McAndrews MP, Rovet JF (2014) Effects of maternal hypothyroidism on offspring hippocampus and memory. Thyroid 24(3): 576-584.

113. Yamaguchi S, Aoki N, Kitajima T, Iikubo E, Katagiri S, et al. (2012) Thyroid hormone determines the start of the sensitive period of imprinting and primes later learning. Nat Commun 3: 1081.

\section{Your next submission with Juniper Publishers} will reach you the below assets

- Quality Editorial service

- Swift Peer Review

- Reprints availability

- E-prints Service

- Manuscript Podcast for convenient understanding

- Global attainment for your research

- Manuscript accessibility in different formats

( Pdf, E-pub, Full Text, Audio)

- Unceasing customer service

Track the below URL for one-step submission https://juniperpublishers.com/online-submission.php 